\title{
Bovine Serum as an Alternative to Control Serum for Total Protein Levels
}

\author{
Bambang Supriyanta $^{1,2 *} \mathbb{D}$, Martha Atik Martsiningsih ${ }^{1} \mathbb{D}$, Steven Soenjono ${ }^{3} \mathbb{D}$, Audrey Amy Andreansyah ${ }^{1}$, Budi Setiawan ${ }^{1,2} \mathbb{D}$ \\ ${ }^{1}$ Department of Medical Laboratory Technology, Politeknik Kesehatan Kemenkes Yogyakarta, Yogyakarta, Indonesia; ${ }^{2}$ Pusat \\ Unggulan IPTEK Inovasi Teknologi Terapan Kesehatan Masyarakat, Politeknik Kesehatan Kemenkes Yogyakarta, Yogyakarta, \\ Indonesia; ${ }^{3}$ Department of Environmental Health, Politeknik Kesehatan Kementerian Kesehatan Manado, Manado, Indonesia
}

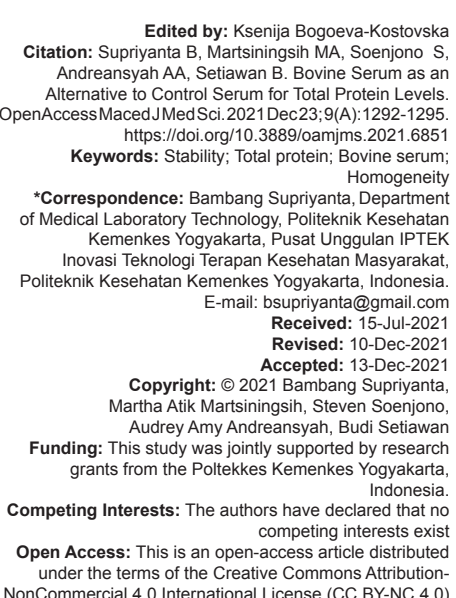

\section{Abstract}

BACKGROUND: Total protein describes the liver's ability to synthesize protein and metabolize substances in the blood.

AIM: We aimed to investigate whether cow serum can be used as a control agent because the analyte in bovine blood serum is almost the same as that of humans.

METHODS: Homogeneity and stability of bovine serum by adding $7.5 \%$ ethylene glycol preservative after being stored for 12 weeks at $-20^{\circ} \mathrm{C}$. This study uses a one-group pretest-posttest design. The alternative serum is derived from cow blood waste at a slaughterhouse in Giwangan, Yogyakarta, Indonesia. Data analysis was based on ISO 13528:2005 regarding stability and homogeneity of control serum.

RESULTS: From the examination of the total protein level in the serum, the value of $\mathrm{Xr}-\mathrm{Yr}=0.23817$; this value meets the test criteria $|\mathrm{Xr}-\mathrm{Mr}| 0.3 \sigma$, that is $0.23817 \leq 0.91585$

CONCLUSION: Based on the results, serum from bovine can be an alternative to assess total protein levels and is still stable and homogeneous even though it is stored for 12 weeks.

\section{Introduction}

The assessment of total protein is needed to monitor the risk of liver and kidney disease. On the liver by describing the ability to synthesize proteins and metabolize substances contained in the blood [1].

Quality control is needed to detect analytical errors that affect laboratory test results [2]. There are two types of control materials, namely, modified control materials and commercial control materials. Commercial control serum is widely used in laboratories today [3] but commercial control materials are relatively more expensive for developing countries [4].

Control materials can be made from human, animal, or pure chemicals that can be traced to Standard Reference Materials. Bovine blood can be used as a control material by processing bovine blood into the serum. Bovine blood is blood waste from slaughtering animals that have not been used optimally. Utilization of bovine serum as a control material because the total protein analyte contained in bovine blood serum is the same as in human serum [5]. The selection of control material using bovine serum aims to avoid the risk of hepatitis infection and HIV-causing agents from human serum [6]. The use of control serum derived from bovine blood can be an alternative because of its low cost.

In its manufacture, the control material must have homogeneous and stable conditions during the storage period [5]. Stability is carried out to ensure that the test sample does not experience significant changes at any level. The stability of the control serum can be used to assess laboratory performance, including the quality of equipment and reagents. Therefore, the stability of the control serum is crucial [7].

The use of pooled serum with the addition of ethanediol can maintain the stability of the total protein content for 30 days at a temperature of $-20^{\circ} \mathrm{C}$ [8]. The study was conducted using a bovine serum with a storage period of 12 weeks. This needs to be done to know the length of time the use of control serum. 


\section{Methods}

This study uses an analytical survey method. The research design used is one group pretestposttest, with the calculation of ISO 13528 in 2005 [9]. Bovine serum was declared homogeneous if $\mathrm{Ss} \leq 0.3 \sigma$ standard deviation for the proficiency assessment (SDPA). Determination of the value of SDPA is calculated based on ISO 13528:2005 by Horwitz and modified by Thompson. The total protein level of bovine serum was assessed using the TMS 30i tool with the Biuret method. This method is based on colorimetry (spectrophotometry), in which proteins from purple polypeptides are associated with copper ions in a strongly alkaline solution [10].

Table 1: Total cow serum protein levels before and after storing for 12 weeks at $-20^{\circ} \mathrm{C}$

\begin{tabular}{lllllll}
\hline $\begin{array}{l}\text { Treatment } \\
\text { (week) }\end{array}$ & $\mathrm{N}$ (Duplo) & \multicolumn{3}{l}{ Total protein } & & \\
\cline { 3 - 7 } & & Maximum & Minimum & Average & $\begin{array}{l}\text { Standard } \\
\text { Deviation }\end{array}$ & $\begin{array}{l}\text { Coevisien } \\
\text { Variation (\%) }\end{array}$ \\
\hline 0 & 10 & 5.65 & 6.17 & 6.02 & 0.14 & 2.25 \\
12 & 3 & 5.76 & 5.81 & 5.78 & 0.02 & 0.39 \\
\hline
\end{tabular}

This study used bovine blood waste obtained from the Giwangan Slaughterhouse, Yogyakarta. Bovine blood waste comes from bovine blood, which can stand for a while after the flow is not strong and is accommodated in a $15 \mathrm{ml}$ centrifuge tube. The blood obtained was then centrifuged to collect serum that met the criteria, namely not hemolysis, not lipemic, and not icteric because it will affect the measurement results [11]. In this study, $80 \mathrm{ml}$ of serum samples were obtained, which were then added $6.03 \mathrm{ml}$ of ethylene glycol.

Table 2: Homogeneity test

\begin{tabular}{|c|c|c|c|c|c|c|c|}
\hline \multirow[t]{2}{*}{ Sample } & \multicolumn{2}{|c|}{ Result } & \multirow[t]{2}{*}{$x_{t}$} & \multirow[t]{2}{*}{$X_{t}-X_{r}$} & \multirow[t]{2}{*}{$\left(X_{t}-X_{r}\right)^{2}$} & \multirow[t]{2}{*}{$W_{t}$} & \multirow[t]{2}{*}{$W_{t}^{2}$} \\
\hline & $1^{\mathrm{st}}$ & $2^{\text {nd }}$ & & & & & \\
\hline 14 & 6.12 & 6.11 & 6.115 & 0.0935 & 0.00874225 & 0.01 & 0.00 \\
\hline 11 & 6.02 & 6.03 & 6.025 & 0.0035 & 0.00001225 & -0.01 & 0.00 \\
\hline 33 & 5.67 & 5.65 & 5.660 & -0.3615 & 0.13068225 & 0.02 & 0.00 \\
\hline 9 & 6.03 & 5.93 & 5.980 & -0.0415 & 0.00172225 & 0.1 & 0.01 \\
\hline 1 & 6.05 & 6.06 & 6.055 & 0.0335 & 0.00112225 & -0.01 & 0.00 \\
\hline 17 & 6.05 & 6.07 & 6.060 & 0.0385 & 0.00148225 & -0.02 & 0.00 \\
\hline 16 & 6.08 & 6.09 & 6.085 & 0.0635 & 0.00403225 & -0.01 & 0.00 \\
\hline 4 & 6.17 & 6.17 & 6.170 & 0.1485 & 0.02205225 & 0 & 0.00 \\
\hline 40 & 6.06 & 6.06 & 6.060 & 0.0385 & 0.00148225 & 0 & 0.00 \\
\hline \multirow[t]{8}{*}{61} & 6.01 & 6.00 & 6.005 & -0.0165 & 0.00027225 & 0.01 & 0.00 \\
\hline & & $\Sigma$ & 60.215 & $\Sigma$ & 0.17160250 & $\Sigma$ & 0.01 \\
\hline & & $X_{r}$ & 6.0215 & & & & \\
\hline & & & $S_{x}$ & 0.13808 & $S_{w}$ & 0.02377 & \\
\hline & & & $S_{x}^{x}{ }^{2}$ & 0.01907 & $S_{w}{ }^{2}$ & 0.00057 & \\
\hline & & & & & $S_{w}^{2} / 2$ & 0.00028 & \\
\hline & & & & & $S_{x}^{2}-\left(S_{w}^{2} / 2\right)$ & 0.01878 & \\
\hline & & & & & $S_{s}$ & 0.13706 & \\
\hline
\end{tabular}

$X_{i}$ : The average total protein content of the $1^{\mathrm{st}}$ and $2^{\text {nd }}$ examinations $(\mathrm{g} / \mathrm{d}), \mathrm{X}_{\mathrm{r}}$ : The average total protein
content of the $1^{\text {st }}$ and $2^{\text {nd }}$ examinations of the $1^{\text {st }}$ to $10^{\mathrm{th}}$ samples $(\mathrm{g} / \mathrm{d})$. W: The difference between the total protein levels of the $1^{\text {st }}$ and $2^{\text {nd }}$ examinations, which were absolute $(\mathrm{g} / \mathrm{dll}), \Sigma:$ Total, $\mathrm{S}_{x}$ : Sample mean standard deviation, $\mathrm{S}_{\mathrm{w}}$ : Standard deviation within samples, $\mathrm{S}_{\mathrm{s}}$ : Standard deviation between samples.

Evaluation of total protein levels was carried out before storage and after 12 weeks of storage. A homogeneity test was carried out before storage, and ten samples were taken in duplicate. Examination of total protein levels after 12 weeks was carried out as a stability test which took three samples in duplicate.

This study used bovine serum with $7.5 \%$ ethylene glycol, stored for 12 weeks at $-20^{\circ} \mathrm{C}$. Ethylene glycol is one of the recommended preservatives for control materials because it has antifreeze and antibacterial properties [6]. According to research by Fauziah et al. [12] the stability of glucose levels in pooled sera with $7.5 \%$ ethylene glycol was statistically and clinically stable until day 30 . The stability of glucose levels in pooled sera with $1 \%$ sodium azide was statistically stable until day 8 , while clinically stable until day 25 [12]. The storage stability of the control serum at $-20^{\circ} \mathrm{C}$ was relatively better [13]. This research has received approval from the Ethics Committee of the Health Polytechnic of the Ministry of Health of Yogyakarta by obtaining an ethical clearance letter e-KEPK/POLKESYO/0174/II/2021.

\section{Results and Discussion}

Based on the results of the study, the results are as in the following Tables 1-3.

Table 3: CV Horwitz result for homogeneity test

\begin{tabular}{ll}
\hline CV Horwitz & $2^{1-0,5 \log C}$ \\
Average Concentration & 6.0215 \\
Unit & Percent \\
Concentration Faction (C) & 0.0602 \\
Log C & -1.22030 \\
0,5 Log C & -0.61015 \\
$1-0,5$ Log C & 1.61015 \\
$2^{1-0,5} \log C$ & 3.05283 \\
$C V_{\text {Horwitz }}$ & 3.05283 \\
$0.3 \sigma(0.3 \times C V$ Horwitz) & 0.91585 \\
\hline
\end{tabular}

Based on ISO 13528:2005, bovine serum samples are considered homogeneous if $\mathrm{Ss}$ is $0.3 \sigma$. The SDPA determined by $\mathrm{CV}$ Horwitz is shown in Table 3 of 3.05283 , and the value of $0.3 \sigma$ is 0.91585 . In Table 2, the homogeneity test results obtained an Ss value of 0.13706 , so that the sample was declared homogeneous because it was following the criteria of ISO 13528:2005 Ss 0.3 $\sigma$, namely $0.13706 \leq 0.91585$. To determine the stability of bovine serum was stored at $4 \mathrm{C}$ for 12 weeks. After being stored at at $-20^{\circ} \mathrm{C}$ for 12 weeks, total protein was examined using the Biuret method. The results of the examination are in Table 4.

Table 4: Data on examination of total protein levels and calculation of ISO 13528 stability test in 2005

\begin{tabular}{llll}
\hline No Sample & \multicolumn{2}{l}{ Result } & $\mathrm{Y}_{\mathrm{t}}$ \\
\cline { 2 - 3 } & 1 & 2 & \\
\hline 22 & 5.77 & 5.76 & 5.77 \\
54 & 5.81 & 5.8 & 5.81 \\
65 & 5.8 & 5.76 & 5.78 \\
& & $\mathrm{Y}_{\mathrm{r}}$ & 5.7833 \\
\hline
\end{tabular}

According to ISO 13528:2015, the control material is stable if the value of $|\mathrm{Xr}-\mathrm{Yr}| 0.3 \sigma$. Based on the examination of the total protein content in Table 4, the $\mathrm{Yr}$ value of 5.7833 was obtained. Value of $|\mathrm{Xr}-\mathrm{Yr}|=$ 0.2382 , so that the value meets the stability test criteria according to $|\mathrm{Xr}-\mathrm{Yr}| 0.3 \sigma$, that is, $0.2382 \leq 0.91585$. 
The homogeneity and stability test results show a good CV (bovine serum CV calculation results $=2.25 \%$ ) because it is still below the maximum CV according to the 2013 Minister of Health of Indonesia Regulation, $3 \%$. The precision value is used to indicate how close the results of repeated examinations are with the same sample. A decrease in the $\mathrm{CV}$ value yields an increase in the accuracy of the system/ method.

The average total protein content in Table 3 decreased by $0.24 \mathrm{~g} / \mathrm{dl}$ or $3.96 \%$. The decrease in total protein content can be caused by the fast-freezing process and the slow thawing process, damaging the protein [14]. The refreezing cycle can also affect the total protein content. Refreezing cycles can result in changing trends, therefore limiting freeze or thaw cycles is highly recommended [15].

In a previous study, pooled sera added with ethanediol (ethylene glycol) stored at $4-8^{\circ} \mathrm{C}$ was stable for 18 days [16]. In contrast to this study, which used bovine serum with the addition of ethylene glycol $7.5 \%$, which was stored for 12 weeks at a temperature of $-20^{\circ} \mathrm{C}$ to the total protein content. The temperature of $-20^{\circ} \mathrm{C}$ is relatively better for storage stability of control serum compared to refrigeration [13].

According to a previous study, the total protein content in pooled sera without preservatives changed significantly at $-20^{\circ} \mathrm{C}$ after three months of storage [17]. In contrast to the research conducted, bovine serum was added with $7.5 \%$ ethylene glycol preservative, stored at $-20^{\circ} \mathrm{C}$ for 12 weeks, and remained stable. Ethylene glycol has antifreeze and antibacterial properties, which allow maintaining the stability of bovine serum [6]. The increase in total protein content can be associated with the release of protein from glycoproteins and increased bacterial activity producing several enzymes and other microbial products that contribute to increasing protein levels [18]. The use of ethylene glycol preservative was more stable than sodium azide preservative where clinically pooled sera added with $7.5 \%$ ethylene glycol was stable for up to 30 days, while $1 \%$ sodium azide added was stable for up to 25 days [12].

The limitation of this study was that there was no control using commercial control serum, so there was no comparison test to validate the results of alternative control serum tests.

\section{Conclusion}

Based on the research that has been done, the total protein content in bovine serum with the addition of $7.5 \%$ ethylene glycol preservative, which was stored for 12 weeks at $-20^{\circ} \mathrm{C}$, was homogeneous and stable.

\section{References}

1. Sujono S, Maulida YA, Sari MP. Total protein and urea levels with and without the addition of $\gamma$-cyclodextrin in lipemic serum. J Teknol Laboratorium. 2016;5(1):16-9.

2. Sukorini U, Nugroho DK, Rizki M, Hendriawan PJ. Pemantapan Mutu Internal Laboratorium Klinik. Yogyakarta: Kanalmedika dan Alfamedia; 2010.

3. Muhammad M, Yayuk K, Endah Y. Pemanfaatan pool serum sebagai bahan kontrol ketelitian pemeriksaan glukosa darah. Med Lab Technol J. 2015;1(2):54-60.

4. Salma FD, Rgdgyu LA, Kurnaeni N, Rinaldi SF. Cost effectiveness analysis (CEA) of commercial control materials and patient serum pools. J Riset Kesehatan Poltekkes Depkes Bandung. 2019;11(1):293-8.

5. Deom A, El Aouad R, Heuck CC, Kumari S, Lewis SM, Uldall A, et al. Requirements and Guidance for External Quality Assessment Schemes for Health Laboratories. Geneva: World Health Organization; 1999.

6. Browning DM, Hill PG, Olaz'abal R, V'azquez DA, World Health Organization, Health Laboratory Technology Unit. Preparation of Stabilized Liquid Quality Control Serum to be Used in Clinical Chemistry. Geneva: World Health Organization; 1986.

7. Handayati A, Christyaningsih J, Rini T. Stability test of pooled sera stored in freezer for internal quality assurance in clinical laboratory. J Penelitian Kesehatan. 2014;12(1):1-6.

8. Kulkarni S, Pierre SA, Kaliaperumal R. Efficacy of pooled serum internal quality control in comparison with commercial internal quality control in clinical biochemistry laboratory. J LabPhysicians 2020;12(3):191-5. https://doi.org/10.1055/s-0040-1721151 PMid:33293781

9. International Organization for Standardization. Statistical Methods for Use in Proficiency Testing by Interlaboratory Comparisons. London, United Kingdom: International Organization for Standardization; 2005.

10. Tothova C, Nagy O, Kovac G. Serum proteins and their diagnostic utility in veterinary medicine: A review. Vet Med. 2016;61(9):475-96.

11. Pambudi AF, Widada ST, Setiawan B. Lipemic serum with gamma-cyclodextrin flocculants on glucose examination. Med Lab Technol J. 2017;3(2):68-72.

12. Fauziah S, Riyani A, Rinaldi SF, Kurnaeni N. Comparison of the stability of blood glucose levels in pooled sera added with ethylene glycol and sodium azide. J Riset Kesehatan Poltekkes Depkes Bandung. 2019;11(2):287-93

13. Soehartini S, Dra MS, Suhadi B. Pembuatan Serum Kontrol Untuk Kimia Klinik Dengan Menggunakan Etilen Glikol; 1996.

14. Cao E, Chen Y, Cui Z, Foster PR. Effect of freezing and thawing rates on denaturation of proteins in aqueous solutions. Biotechnol Bioeng. 2003;82(6):684-90. https://doi.org/10.1002/ bit.10612

PMid:12673768

15. Mitchell BL, Yasui Y, Li Cl, Fitzpatrick AL, Lampe PD. Impact of freeze-thaw cycles and storage time on plasma samples used in mass spectrometry based biomarker discovery projects. Cancer Inform. 2005;1(1):98-104.

PMid:19305635 
16. Tambse VP, Manoorkar GS, Banik MM, Tambse MP. Study of the stability of various biochemical analytes in pooled sera preserved at 4-8 o C. Asian J Biomed Pharm Sci. 2015;5(48):38.

17. Cuhadar S, Koseoglu M, Atay A, Dirican A. The effect of storage time and freeze-thaw cycles on the stability of serum samples. Biochem Med (Zagreb). 2013;23(1):70-7. https://doi. org/10.11613/bm.2013.009

PMid:23457767

18. Jamtsho R. Stability of lyophilized human serum for use as quality control material in Bhutan. Indian $\mathrm{J}$ Clin Biochem. 2013;28(4):418-21. https://doi.org/10.1007/s12291-013-0328-x PMid:24426247 